\title{
ELECTROCHEMICAL PROPERTIES OF AI-6060 ALLOY AFTER INDUSTRIAL-SCALE ECAP
}

\author{
A. YULINOVA, D. NICKEL, P. FRINT, T. LAMPKE \\ Chemnitz University of Technology, Institute of Materials Science and Engineering, Germany
}

Equal-channel angular pressing (ECAP) as the most famous method of severe plastic deformation has the potential for up-scaling from laboratory to industrial. Therefore, it is important to examine practice-relevant properties of large billets deformed by this process. Mechanical properties and corrosion resistance essentially influence the service life of construction components. Mechanical properties of an Al-6060 alloy after industrial-scale ECAP (cross-section of the billet $50 \times 50 \mathrm{~mm}$ ) have been analyzed by P. Frint $[4,17]$. The effect of one pass of industrial-scale ECAP on the electrochemical properties of an Al-6060 alloy by means of potentiodynamic polarization tests in $0.1 \mathrm{M} \mathrm{NaCl}$ solution is investigated. The corroded surfaces were analyzed by means of optical microscopy. In order to characterize the homogeneity of the corrosion behaviour of the ECAP-processed material, all analyzes were taken in different zones perpendicular to the extrusion axis. The results indicate that one ECAP pass does not deteriorate the electrochemical behaviour of the Al-6060 alloy.

Keywords: equal-channel angular pressing (ECAP), corrosion, aluminium alloy.

Equal-channel angular pressing or extrusion (ECAP/E) as a method to produce severe plastic deformation was described in its first version by V. M. Segal [1]. During the deformation process, the billet is pressed through a bent channel within a die whose angle is usually equal to, or very close to $90^{\circ}$ (Fig. 1). Shear induced in the sample by this process results in the grain reduction and fragmentation of the precipitations. The same sample may be pressed repetitively to achieve essentially higher strains in the material, which causes microstructure changes from fine-grained to ultrafine-grained.

Fig. 1. Principle of ECAP process and sample-taking. 6060 E1_opt(a) - samples from the upper part and $6060 \mathrm{E} 1 \_$opt(b) samples from the lower part

of ECAPed bar after heat treatment for maximal strength.

1 - load; 2 - sample; 3 - die;

4 - channel; 5 - pressed sample.

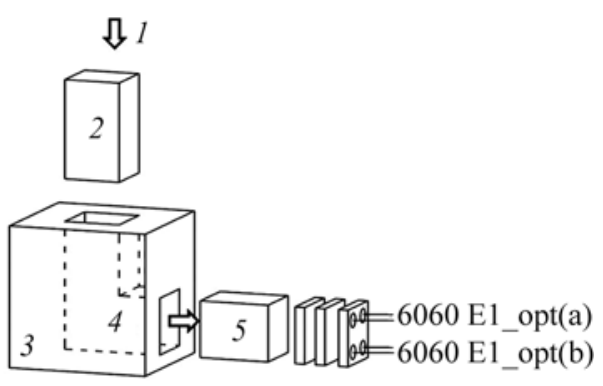

In recent years, ECAP has attracted significant attention due to numerous advantages of deformed materials compared with traditional coarse-grained materials. Particular interest has been put on ECAP processes for aluminium alloys because of their significance for the automotive, aerospace, and construction industry, etc. The exceptional mechanical [1-6] and electrochemical properties have been observed [7-13] for aluminium materials after ECAP deformation.

Corresponding author: A. YULINOVA, e-mail: alexandra.yulinova@mb.tu-chemnitz.de 
While the ECAP technique has the potential for up-scaling from laboratory to industrial scale due to the possibility to produce deformation without changing the shape of material, to the best knowledge of the authors, nothing has been published about corrosion behaviour for industrial-scale ECAP-processed materials until now. Numerous investigations of the corrosion behaviour have been conducted for laboratory-scale (e.g. maximal cross-section of the billet $15 \times 15 \mathrm{~mm}$ ) ECAP-processed aluminium alloys [7-13]. This work analyzes the effect of one pass of industrial-scale ECAP (crosssection of the billet $50 \times 50 \mathrm{~mm}$ ) on the electrochemical properties of an Al-6060 alloy.

Experimental. Two different states of the conventional precipitation-hardened Al-6060 alloy (0.44 wt.\% Si; $0.18 \mathrm{Fe} ; 0.02 \mathrm{Cu} ; 0.03 \mathrm{Mn} ; 0.5 \mathrm{Mg} ; 0.02 \mathrm{Zn} ; 0.01 \mathrm{Ti}$; $0.01 \mathrm{~W}$; bal. Al) were investigated. Two bars (cross-section $50 \times 50 \mathrm{~mm}$ ) were subjected to solid-solution treatment at $525^{\circ} \mathrm{C}$ for $3 \mathrm{~h}$ and quenched in water afterwards. Then, one of the billets was aged at $170^{\circ} \mathrm{C}$ for $13 \mathrm{~h}$ to achieve the precipitation heat state (6060 T6 in the following). The other billet was processed by only one ECAP pass for reasons explained bellow. Subsequently, the samples from this bar were heat-treated at $170^{\circ} \mathrm{C}$ for 20 min to get the state of optimal mechanical properties [4, 5] $(6060 \mathrm{E} 1$ opt in the following). Exemplary optical micrographs (Fig. 2) show the changed microstructure of the material through one ECAP pass. ECAP was carried out at room temperature at a pressing speed of $20 \mathrm{~mm} / \mathrm{s}$ with the backpressure of $100 \mathrm{bar}$. The ECAP die has an internal angle of $\Phi=90^{\circ}$ which causes an effective strain of approximately $1.1[14]$.
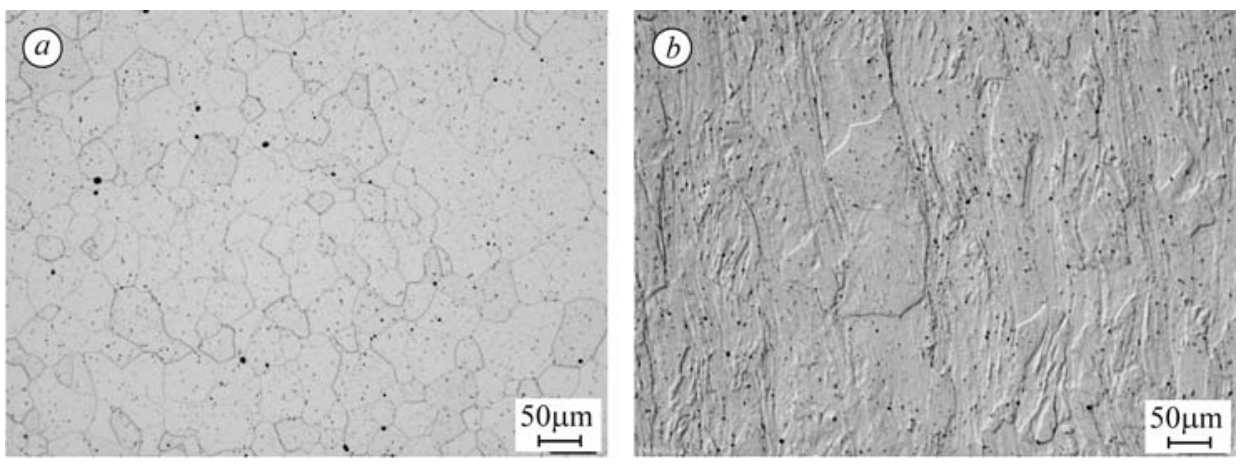

Fig. 2. Optical micrographs of Al-6060: before ECAP (6060 T6) (a) and after ECAP (6060 E1 opt) (b).

An increase in strength and ductility of the Al-Mg-Si alloy after only one pass of laboratory-scale ECAP has been detected by Hockauf et al. [4], making ECAP an attractive process also for industrial applications. The possibility to improve the mechanical properties through one ECAP pass, however, necessitates the analysis of other practice-relevant properties. Frint et al. $[5,6]$ have already investigated the mechanical properties of Al-6060 after one pass of industrial-scale ECAP. It has been established that the optimized combination of ECAP and subsequent heat treatment [4] can be successfully applied also to industrial-scale ECAP to produce the material state exhibiting higher strength at almost equal ductility as common T6-state [5]. The authors have succeeded in optimizing process parameters. The strength and hardness measured from top to bottom of the deformed billet have a relative deviation of less than $7 \%$ and $10 \%$, respectively, compared to commercially extruded materials with around 10\% [6]. In this context, it is important to investigate the electrochemical behaviour of the same material after one pass of industrial-scale ECAP, because both mechanical properties and electrochemical behaviour influence the application of this alloy. 
All samples for polarization tests were cut from the extruded non-ECAPed as well as the ECAPed billet perpendicular to the extrusion direction, mechanically ground and polished.

In oxygen-containing environment, aluminium alloys are covered spontaneously by a natural oxide layer, which prevents corrosion processes. But in the presence of $\mathrm{Cl}^{-}$ions, this oxide layer is locally destroyed and pitting corrosion develops. Therefore, it is important to investigate the electrochemical behaviour of aluminium in $\mathrm{Cl}^{-}$-containing medium. In order to compare the electrochemical behaviour of non-ECAPed and ECAPed samples, potentiodynamic polarization tests were conducted at room temperature in $0.1 \mathrm{M} \mathrm{NaCl}$ aqueous solution using a conventional electrochemical cell with three electrodes (reference electrode $\mathrm{Ag}-\mathrm{AgCl}$, saturated $\mathrm{KCl}$ electrode and $\mathrm{Pt}$ counter electrode). After $20 \mathrm{~min}$ immersion in testing solution, polarization curves were measured up to $10 \mathrm{~mA}$ at a sweep rate of $0.5 \mathrm{mV} / \mathrm{s}$. Corrosion potential $\left(E_{\text {corr }}\right)$ and corrosion current density $\left(i_{\text {corr }}\right)$ were determined by extrapolation using the Tafel equation of at least three measurements for each material. The corroded surfaces were analyzed by means of optical microscopy. For the deformed samples all analyses were taken in different zones (Fig. 1).

Results and discussion. Potentiodynamic polarization of Al-6060 alloy. The average values and the standard deviation of at least three measurements of corrosion potential and corrosion current density for the non-deformed bar and for different zones of the deformed bar are given in Fig. 3. The pitting potential was not defined from the potentiodynamic polarization curves because of the unstable increase in the current density. Both the corrosion potential and the corrosion current density are difficult to be indentified from the polarization curves due to the current density fluctua-

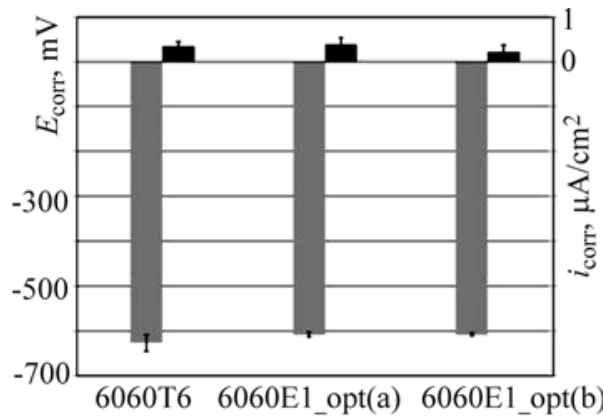

Fig. 3. Corrosion potential ( $\left.E_{\text {corr }}\right)$ and corrosion current density $\left(i_{\text {corr }}\right)$ obtained from polarization curves. tions near the corrosion potential, corresponding to the initiation and repassivation of pitting corrosion [12]. The corrosion potential was determined under the assumption that it conforms to the potential where curves show a clear spike to lower current density. The corrosion potential of Al-6060 without ECAP (6060 T6) is $-627 \pm 18 \mathrm{mV}$; the corrosion current density is around $0.4 \pm 0.1 \mu \mathrm{A} / \mathrm{cm}^{2}$. The corrosion potential and the corrosion current density of the 6060 E1_opt state are almost identical in comparison to that of the $6060 \mathrm{~T} 6$ state with a slight tendency to improved electrochemical behaviour. Furthermore, it has to be emphasized that the polarization curves and the determined electrochemical parameters for different zones (upper and lower parts of a deformed bar) of the deformed samples (Fig. 3) are very similar. This indicates that the electrochemical behaviour of the Al-6060 alloy is generally close to being homogeneous after one pass of industrial-scale ECAP. Owing to the scattered values of corrosion potential and corrosion current density, further investigations have to be performed to confirm the proposed homogeneity.

Surface observation of corroded Al-6060 alloy. Optical micrographs of nonECAPed and ECAPed samples after potentiodynamic polarization up to $10 \mathrm{~mA}$ (for ECAPed samples one example from the upper part) are shown in Fig. 4. For each state, two representative images were chosen to present the inhomogeneously distributed corrosion signs being in agreement with the scattered electrochemical parameters mentioned above. For both states pitting corrosion is clearly observable. Main alloying 
elements added to the Al-6060 alloy to improve the mechanical strength are $\mathrm{Mg}$ and $\mathrm{Si}$, which form fine hardening precipitates $\mathrm{Mg}_{2} \mathrm{Si}$. The electrode potential of the $\mathrm{Mg}_{2} \mathrm{Si}$ precipitates does not differ much from that of the aluminium matrix so that they do not play a dominant role for the initiation of pitting corrosion $[15,16]$. But the Fe-, Mnand Si-rich impurities $(2 \ldots 5 \mu \mathrm{m})$, which are noble compared to the matrix and therefore act as microcathode, induce preferred dissolution of the $\mathrm{Al}$ matrix close to these precipitates and make Al-6060 susceptible to localized corrosion such as pitting corrosion $[7,15,16]$. These impurities are the most critical sites for the evolution of pitting corrosion as it is seen from Fig. 5.
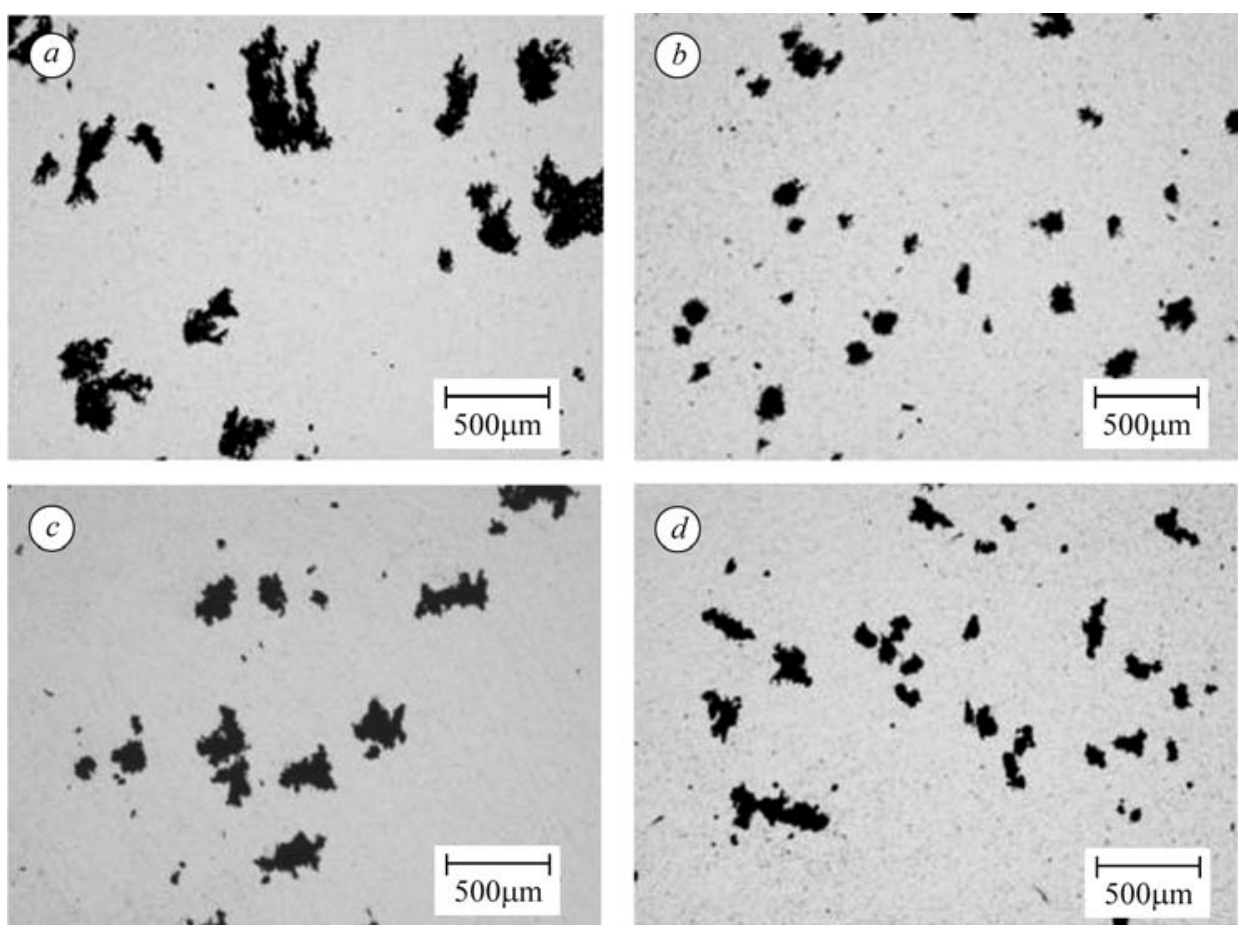

Fig. 4. Optical micrographs of Al-6060 after anodic polarization in $0.1 \mathrm{M} \mathrm{NaCl}$ : $a, b$ - before ECAP (6060 T6); $c, d$ - after ECAP (6060 E1_opt).
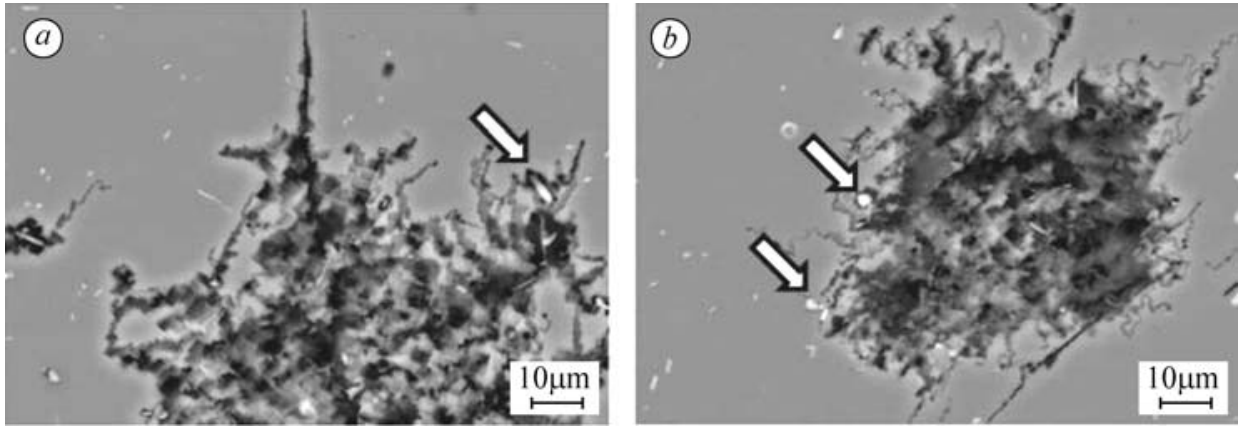

Fig. 5. SEM micrographs of pittings with Fe-, Mn- and Si-rich impurities: $a$ - before ECAP (6060 T6); $b$ - after ECAP (6060 E1_opt).

The improved corrosion resistance after ECAP deformation caused through the changed microstructure of materials, i. e. through fragmentation of precipitations and grain refinement was observed by other authors [7-10,12]. But these investigations were made for samples which were processed by laboratory-scale ECAP. This study 
shows that the electrochemical behaviour of Al-6060 is not worsened after up-scaling of ECAP to industrial scale. It is an important finding in combination with knowing that the mechanical properties will be significantly improved even through one ECAP pass [4-6].

The effect of further ECAP passes on the electrochemical behaviour is under investigation. As has been found for other $\mathrm{Al}$ alloys [7-10, 12], it is suggested that the phases which cause pitting corrosion (Fe-containing phases in Al-6060) have been reduced and more homogeneously distributed in the matrix through ECAP processing. The grains are also more refined. This can result in the formation of smaller and fewer pits by anodic polarization. This hypothesis will be proved in future work.

Deformation not only influences the grain and precipitation size but also the texture of the material is significantly changed even after one ECAP pass. It has been established that in many $\mathrm{Al}$ alloys pits propagate by forming tunnels which grow in $<100>$ directions and are bounded by $\{100\}$ planes [17]. The role of the texture on the change of corrosion behaviour of Al-6060 after ECAP deformation of the large billet will be investigated in future research, too.

\section{CONCLUSION}

The influence of one pass of industrial-scale ECAP on the electrochemical properties of an Al-6060 alloy was investigated using potentiodynamic polarization tests in $0.1 \mathrm{M} \mathrm{NaCl}$. ECAPed material shows no significant change in the corrosion potential and corrosion current density. Thus, no worsening of the electrochemical corrosion behaviour of the Al alloy by means of ECAP can be concluded from the polarization curves. The corrosion damage correlates with the results of the potentiodynamic polarization tests. It is important to note that the electrochemical behaviour is comparatively homogeneous throughout the whole cross-section of the industrial-scale semi-finished product.

PЕЗЮМЕ. Вплив одноразового рівноканального кутового пресування на електрохімічні властивості сплаву Al-6060 досліджено методом потенціодинамічної поляризації в $0,1 \mathrm{M}$ розчині $\mathrm{NaCl}$. Поверхню після корозії обстежено за допомогою оптичної мікроскопії. Для опису гомогенності характеру корозії матеріалу проаналізовано різні зони, перпендикулярні осі пресування. Виявлено, що воно не змінює електрохімічну поведінку сплаву.

РЕЗЮМЕ. Влияние однократного равноканального углового прессования на электрохимические свойства сплава Al-6060 исследовано методом потенциодинамической поляризации в $0,1 \mathrm{M}$ растворе $\mathrm{NaCl}$. Поверхность после коррозии обследовано с помощью оптической микроскопии. Для описания гомогенности характера коррозии материала проанализированы разные зоны, перпендикулярные оси прессования. Выявлено, что оно не изменяет электрохимическое поведение сплава.

Acknowledgment. The results presented in this paper have been obtained in the framework of the IGF project 16831 BG. This project of the Association for the Research Institute for Precious Metals and Metals Chemistry (Verein für das Forschungsinstitut für Edelmetalle und Metallchemie) has been carried out within the AiF (Arbeitsgemeinschaft industrieller Forschungsvereinigungen „Otto von Guericke“ e.V. (AiF)) programme to promote joint industrial research and development (Industrielle Gemeinschaftsforschung - IGF) and has been funded by the German Federal Ministry of Economics and Technology (BMWi) on the basis of a decision of the German Bundestag.

1. Plastic working of metals by simple shear / V. M. Segal, V. I. Reznikov, A. E. Drobyshevskiy, V. I. Kopylov // Russian Metallurgy (Mettaly). - 1981. - 1. - P. 99-105.

2. Valiev R. Z. and Langdon T. G. Principles of equal-channel angular pressing as a processing tool for grain refinement // Progress in Mater. Sci. - 2006. - 51. - P. 881-891. 
3. El-Danaf E. A. Mechanical properties and microstructure evolution of 1050 aluminum severely deformed by ECAP to 16 passes // Mater. Sci. and Engng. A. - 2008. - 487. - P. 189-200.

4. Simultaneous improvement of strength and ductility of $\mathrm{Al}-\mathrm{Mg}-\mathrm{Si}$ alloys by combining equalchannel angular extrusion with subsequent high-temperature short-time aging / M. Hockauf, L. W. Meyer, B. Zillmann et al. // Ibid. - 2009. - 503. - P. 167-171.

5. Erfassung von Effekten beim Skalieren von ECAP am Beispiel einer 6000er Aluminiumlegierung / P. Frint, T. Halle, M. F.-X. Wagner et al. // Materialwissenschaft und Werkstofftechnik. - 2010. - 41, № 9. - P. 814-821.

6. Microstructural Features and Mechanical Properties after Industrial Scale ECAP of an Al-6060 Alloy / P. Frint, M. Hockauf, T. Halle et al. // Materials Science Forum. - 2011. - 667-669. - P. 1153-1158.

7. Mechanical properties and corrosion behavior of ultrafine-grained AA6082 produced by equal-channel angular pressing / M. Hockauf, L. W. Meyer, D. Nickel et al. // J. of Mater. Sci. - 2008. - 4. - P. 7409-7417.

8. Effect of equal-channel angular pressing on pitting corrosion resistance of anodized aluminum-copper alloy/ I.-J. Son, H. Nakano, S. Oue et al. // Transactions of Nonferrous Metals Society of China. - 2009. - 19. - P. 904-908.

9. Effect of the number of ECAP pass time on the electrochemical properties of $1050 \mathrm{Al}$ alloys / M.-K. Chung, Y.-S. Choi, J.-G. Kim et al. // Mater. Sci. and Engng. A. - 2004. - 366. - P. 282-291.

10. Improving corrosion resistance of Al-11mass \% Si alloy through a large number of ECAP passes / J.-H. Jiang, A.-B. Ma, F.-M. Lu et al. // Mater. and Corr. - 2011. - 62, № 9. - P. 848-852.

11. Corrosion behavior of ultra-fine grained industrial pure Al fabricated by ECAP / D. Song, A.-B. Ma, J.-H. Jiang et al. // Transactions of Nonferrous Metals Society of China. - 2011. - 19. - P. 1065-1070.

12. Effects of severe plastic deformation on the corrosion behavior of aluminum alloys / E. Akiyama, Z. Zhang, Y. Watanabe, and K. Tsuzaki // J. of Solid State Electrochemistry. - 2009. - 13. - P. 277-282.

13. Impact of ultrafine-grained microstructure on the corrosion of aluminium alloy AA2024 / J. G. Brunner, N. Birbilis, K. D. Ralston, and S. Virtanen // Corr. Sci. - 2012. - 57. - P. 209-2014.

14. Principle of eqaul-channel angular pressing for the processing of ultra-fine grained materials / Y. Iwahashi, J. T. Wang, Z. Horita et al. // Scripta Materialia. - 1996. - 35, № 2. - P. 143-146.

15. Bloeck M. and Furrer P. Vermeidung von Korrosionsproblemen bei Aluminiumwerkstoffen // Mater. and Corr. - 1995. - 46, № 11.- P. 622-627.

16. The influence of $\mathrm{MgSi}$ particle reactivity and dissolution processes on corrosion in $\mathrm{Al}-\mathrm{Mg}-\mathrm{Si}$ alloys / F. Eckermann, T. Suter, P. J. Uggowitzer et al. // Electrochemica Acta. - 2008. - 54, № 2. - P. 844-855.

17. Newman R. C. Local chemistry considerations in the tunnelling corrosion of aluminium // Corr. Sci. - 1995. - 37, № 3. - P. 527-533. 